\title{
Springtime Arctic aerosol: Smoke versus haze, a case study for March 2008
}

\author{
M. Stock ${ }^{a}$, C. Ritter ${ }^{a, *}$, A. Herber ${ }^{b}$, W. von Hoyningen-Huene ${ }^{d}$, K. Baibakov ${ }^{\text {b,c }}$, J. Gräser ${ }^{a}$, T. Orgis ${ }^{a}$, \\ R. Treffeisen ${ }^{\mathrm{b}}$, N. Zinoviev ${ }^{\mathrm{e}}$, A. Makshtas ${ }^{\mathrm{e}}$, K. Dethloff $^{\mathrm{a}}$ \\ ${ }^{a}$ Alfred Wegener Institute for Polar and Marine Research in the Helmholtz Association, Telegrafenberg A 43, 14473 Potsdam, Germany \\ ${ }^{\mathrm{b}}$ Alfred Wegener Institute for Polar and Marine Research in the Helmholtz Association, Bürgermeister-Schmidt-Straße 20, 27568 Bremerhaven, Germany \\ ${ }^{\mathrm{C}}$ Centre for Research and Applications in Remote Sensing (CARTEL), Université de Sherbrooke, 2500, boul. de l'Université, Sherbrooke, Québec J1K 2R1, Canada \\ ${ }^{\mathrm{d}}$ University Bremen, Otto-Hahn-Allee 1, 28359 Bremen, Germany \\ ${ }^{\mathrm{e}}$ Arctic and Antarctic Research Institute, Bering Street 38, 199397 St. Petersburg, Russia
}

\section{A R T I C L E I N F O}

\section{Article history:}

Received 31 March 2011

Received in revised form

15 June 2011

Accepted 16 June 2011

\section{Keywords:}

Arctic Haze

Arctic Smoke

Aerosol

Photometer

Lidar

\begin{abstract}
A B S T R A C T
During March 2008 photometer observations of Arctic aerosol were performed both at a Russian ice-floe drifting station (NP-35) at the central Arctic ocean $\left(56.7-42.0^{\circ} \mathrm{E}, 85.5-84.2^{\circ} \mathrm{N}\right)$ and at Ny-Ålesund, Spitsbergen $\left(78.9^{\circ} \mathrm{N}, 11.9^{\circ} \mathrm{E}\right)$. Next to a persistent increase of AOD over NP-35, two pronounced aerosol events have been recorded there, one originating from early season forest fires close to the city of Khabarovsk ("Arctic Smoke"), the other one showed trajectories from central Russia and resembled more the classical Arctic Haze. The latter event has also been recorded two days later over Ny-Ålesund, both in photometer and lidar. From these remote sensing instruments volume distribution functions are derived and discussed. Only subtle differences between the smoke and the haze event have been found in terms of particle microphysics. Different trajectory analysis, driven by NCEP and ECMWF have been performed and compared. For the data set presented here the meteorological field, due to sparseness of data in the central Arctic, mainly limits the precision of the air trajectories.
\end{abstract}

(c) 2011 Elsevier Ltd. All rights reserved.

\section{Introduction}

In the Arctic troposphere increased aerosol loads can occur during spring, a phenomenon which is called Arctic Haze (Quinn et al., 2007). The radiation impact of this aerosol is still poorly understood. Moreover, the Arctic environment is very vulnerable during that season, as aerosol deposition on snow or ice covered surfaces reduces the albedo and favors an earlier onset of the melting season (Flanner et al., 2007; Clarke and Noone, 2007; Stroeve et al., 2007). The direct forcing of aerosol depends, among other factors, on its soot content (Stone et al., 2008; Ramanathan and Carmichael, 2008) and surface albedo. For these reasons a modeling of the radiative impact of aerosol is still challenging and large regional deviations in temperature response, including both warming and cooling, must be considered (Rinke et al., 2004; Treffeisen et al., 2005).

While in earlier studies on Arctic Haze (Rahn, 1981; Barrie, 1986; Yamanouchi et al., 2005; Law and Stohl, 2007) an anthropogenic origin was already shown, several publications during recent years also revealed that biomass burning (as well forest fire as from

\footnotetext{
* Corresponding author.

E-mail address: christoph.ritter@awi.de (C. Ritter).
}

agricultural origin) is one possibly important constituent of Arctic Haze as well (Warneke et al., 2009; Fu et al., 2009; Stohl et al., 2007). However, so far to our knowledge biomass burning aerosol has overwhelmingly been observed in summer over Spitsbergen (Stohl et al., 2006) or due to agricultural flaming in eastern Europe once in May 2006 (Stohl et al., 2007). The extremely large AOD of more than 0.5 at $500 \mathrm{~nm}$ in May 2006 was observed over Ny-Ålesund due to direct transport of polluted air masses caused by a strong Icelandic low in the lowest $3 \mathrm{~km}$ of the troposphere.

On the other hand, biomass burning events turned out to be the main source for air pollution in Alaska already in April 2008 (Warneke et al., 2009, 2010). Generally air transport into the Arctic is facilitated if it occurs isentropically, along paths with constant potential temperature. This means that cold Eurasian sites should be the main source regions for short living pollutants (Barrie, 1986). The economical growth of East Asia may lead to increased pollution entry from this region (Koch and Hansen, 2005) but due to the temperature gradient to the Arctic this transport pattern will predominantly take place in the high troposphere.

There are indications that in Siberia the boreal vegetation is spreading North (Soja et al., 2007) and forest fires might have increased during the 20th century (Kasischke et al., 2004). Furthermore the climate predictions (as unsure as they are in the Arctic) indicate an increase of Siberian fire events for the 21st 
century (Malevsky-Malevich et al., 2008). Therefore it is possible that in the future the "Asian" components of aerosol might become more important than the "European" ones.

The pollution pathways for Arctic Haze can be quite complex which necessitates aerosol measurements, especially in the Russian part. In this paper we present remote sensing measurements of aerosol events at two different Arctic sites, from the Russian drifting ice-flow NP-35 and from Spitsbergen. An early season fire event and "classical" Arctic Haze have been measured and compared with photometer and lidar.

\section{Instrumentation and measurement sites}

The measurements were performed at the AWIPEV Research Base in Ny-Ålesund, Spitsbergen $\left(78.9^{\circ} \mathrm{N}, 11.9^{\circ} \mathrm{E}\right.$, referred to as NyÅlesund) and at the 35 . North Pole Drifting Station (referred to as NP-35). Ny-Ålesund is operated by the German Alfred Wegener Institute of Polar and Marine Research (AWI) and the French Institut polaire français Paul-Emile Victor IPEV. Ny-Ålesund provides a unique infrastructure for atmospheric research in the European Arctic with different scientific facilities, including lidar, sun and star photometer, a BSRN field and daily radio sounding. Some of the measurements are described in Hoffmann et al. (2009).

Since 1937 the Soviet Union and then the Russian Federation has supported frequent scientific expeditions to the central Arctic region, the so called North Pole Drifting Stations. At the NP-35 AWI participated and sent technical equipment for radio soundings and ground based measurements. Also a German engineer took part at this campaign and performed measurements from September 2007 until the beginning of April 2008. From 14.03.2008 till 07.04.2008 sun photometer measurements were manually started whenever the weather situation allowed. During this measurement period the $\mathrm{NP}-35$ drifted from $56.7^{\circ} \mathrm{E}, 85.5^{\circ} \mathrm{N}$ in a westward direction to $42.0^{\circ}$ E, $84.2^{\circ} \mathrm{N}$ (see Fig. 1 ).

\subsection{Sun photometer}

At both measurement sites the same type of sun photometer produced by Dr. Schulz \& Partner GmbH, Germany (http://www. drschulz.com/cnt/) was used. These instruments are able to

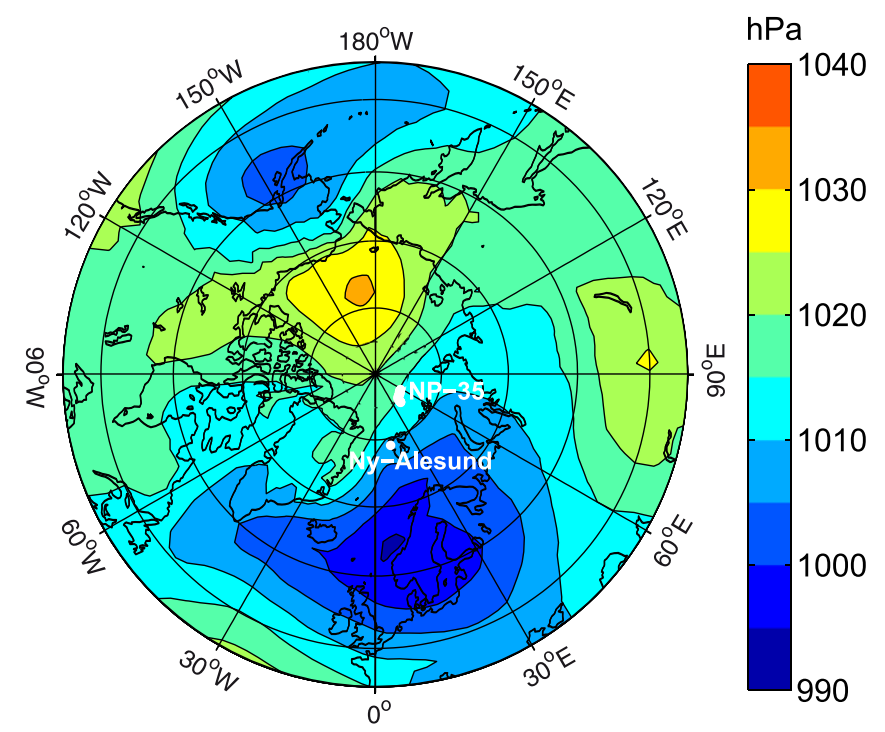

Fig. 1. Mean sea level pressure in hPa of the time period 01.03.2008-31.03.2008 calculated on the basis of 6-hourly ECMWF operational data. White points marking the position of NP-35 in March 2008 and Ny-Ålesund. measure aerosol optical depth (AOD or $\tau_{A}$ ) at 17 wavelengths $\lambda$ in the range of $350 \mathrm{~nm}-1050 \mu \mathrm{m}$ (Herber et al., 2002). The AOD is calculated by eqn. (1) according to WMO (1996) recommendation and the error of the AOD is estimated to be $<0.01(\lambda>400 \mathrm{~nm})$, $<0.02(\lambda<400 \mathrm{~nm})$ respectively (Stock, 2010).

$\tau_{A}(\lambda)=\ln \frac{U_{0}(\lambda)}{U(\lambda) \cdot K} \cdot \frac{1}{m_{A}}-\frac{\tau_{R}(\lambda) \cdot m_{R}+\tau_{O}(\lambda) \cdot m_{O}}{m_{A}}$

Where $U$ is the voltage of the photo diode, $U_{0}$ the calibration voltage, $K$ a correction factor for the changing Sun-Earth distance, $m$ the air mass of ${ }_{A}$ aerosol, o ozone and ${ }_{R}$ Rayleigh. Daily mean column ozone concentrations were derived from ozone soundings and TOMS (Total Ozone Mapping Spectrometer - http://macuv. gsfc.nasa.gov/index.md) measurements. To estimate the fine and coarse particle mode AOD at $500 \mathrm{~nm}\left(\tau_{\text {fine }}, \tau_{\text {coarse }}\right)$, the formalism from O'Neill et al. (2001, 2003) was employed. The Ångström exponent $\alpha$ is calculated based on the empirical concept by Ångström (1929) (see eqn. (2)).

$\tau_{A}(\lambda)=\beta \cdot \lambda^{-\alpha}$

A linear regression of all measured wavelengths in $\ln ($ eqn. (2)) gives $\alpha$.

\subsection{LIDAR}

The Koldewey Aerosol Raman Lidar (KARL) an integral part of the AWIPEV station in Ny-Ålesund. It is a Nd:Yag based system which measures the backscatter coefficient at 355, 532 and $1064 \mathrm{~nm}$ and the extinction coefficient in the former 2 wavelengths from Raman scattering at $\mathrm{N}_{2}$ molecules at $387 \mathrm{~nm}$ and $607 \mathrm{~nm}$. Moreover, the depolarization at $532 \mathrm{~nm}$ and the water vapor are recorded. In 2008, the lidar consisted of a Spectra Pro 290 laser with $50 \mathrm{~Hz}$ and $10 \mathrm{~W}$ per color and a $30 \mathrm{~cm}$ recording telescope with a field of view (fov) of $0.83 \mathrm{mrad}$. More technical details and applications of this lidar can be found in Hoffmann et al. (2009).

For this study the lidar data was evaluated with a resolution of $10 \mathrm{~min}$ and $60 \mathrm{~m}$. As the extraction of the extinction coefficient from lidar data is an ill-posed problem (Pornsawad et al., 2008), any smoothing of the lidar profiles would strongly affect the solution. Hence, no smoothing was applied to the Raman channels. Instead, according to our knowledge for the first time, a statistical approach of all data points in space and time that contained the aerosol event was chosen for analysis. Calculation of backscatter $\left(\beta_{\text {aer }}\right)$ and extinction $\left(\alpha_{\text {aer }}\right)$ was performed according to Ansmann et al. (1992) with the lidar profiles of the mentioned resolution. The backscatter for the infrared (1064 nm) was evaluated according to Klett (1985) with the lidar ratio derived for the $532 \mathrm{~nm}$ channel. Finally, the aerosol depolarization $\left(\delta_{\text {aer }}\right)$ at $532 \mathrm{~nm}$ was calculated from the both backscatter coefficients at parallel and perpendicular polarization according to Behrendt and Nakamura (2002). After the evaluation of the lidar data, hence the backscatter coefficients $\beta_{355 \mathrm{~nm}}^{\text {aer }}, \beta_{532 \mathrm{~nm}}^{\text {aer }}, \beta_{1064 \mathrm{~nm}}^{\text {aer }}$, the extinction coefficients $\alpha_{355 \mathrm{~nm}}^{\text {aer }}, \alpha_{532 \mathrm{~nm}}^{\text {aer }}$ as well as the aerosol depolarization $\delta_{532 \mathrm{~nm}}^{\text {aer }}$ are available, from which the lidar ratios (Liu et al., 2002).

$L R_{\lambda}=\frac{\alpha_{\lambda}^{\mathrm{aer}}}{\beta_{\lambda}^{\mathrm{aer}}}$

and the color ratio

$C R=\frac{\beta_{1064 \mathrm{~nm}}^{\text {aer }} \cdot \beta_{532 \mathrm{~nm}}^{\text {Ray }}}{\beta_{1064 \mathrm{~nm}}^{\text {Ray }} \cdot \beta_{532 \mathrm{~nm}}^{\mathrm{aer}}}$

can be defined. 


\subsection{Meteorological situation and trajectory calculations}

In March 2008 the meteorological conditions in the Arctic were dominated by a high pressure system ranging from the Beaufort Sea over Chukchi Sea and East Siberia to the North Pole (see Fig. 1). A low pressure system was situated at Northern Europe. Both pressure systems caused mainly a north-easterly airflow to Ny-Ålesund and NP-35.

To specify aerosol source regions 5-day backward trajectories were calculated with the Pole-Equator-Pole-Tracer (PEP-Tracer) model (Orgis et al., 2009). The model gives the possibility to calculate an ensemble of trajectories to evaluate the reliability of the trajectories. A number of 1000 starting points in an area of $25 \times 25 \mathrm{~km}^{2}$ around Ny-Ålesund and NP-35 were used to create the ensemble. As input data either operational ECMWF threedimensional wind fields in a grid solution of $2.5^{\circ} \times 2.5^{\circ}$ or NCEP Reanalysis wind fields with the same resolution were used. Additionally the HYSPLIT model (Hybrid Single Particle Lagrangian Integrated Trajectory - Draxler and Rolph (2003)) (also forced by NCEP data) was employed and compared to the PEP-Tracer trajectories. The comparison of these three trajectory calculations is chosen due to the known errors in trajectory computations (Stohl, 1998). In our cases it can be shown that PEP-Tracer with NCEP calculates identical trajectories to HYSPLIT. Larger differences occur between NCEP and ECMWF based PEP-Tracer trajectories.

\section{Biomass burning aerosol at NP-35 (17.03.2008)}

Sun photometer measurements in March 2008 at the NP-35 showed two days (17./21.03.) with unusual high AOD values $\left(\tau_{500 \mathrm{~nm}}>0.3\right.$, see Fig. 2 and Table 1$)$. The trajectory calculations for March 17 in Fig. 3(a) shows the peninsula Kamchatka as source region. A slight difference in horizontal pathways can be seen between PEP-Tracer (NCEP), PEP-Tracer (ECMWF) and HYSPLIT. The horizontal and vertical spread of the trajectories is very low, which indicates stable atmospheric conditions. Warneke et al. (2009) reported biomass burning in Siberia and Kazakhstan in April 2008. Also on the website of the University of Freiburg (http:// www.fire.uni-freiburg.de/GFMCnew/2008/03/0311/20080311_ru. htm) biomass burning fires north of the Amur River along the Russia-China border near the city of Khabarovsk $\left(48.48^{\circ} \mathrm{N}\right.$,

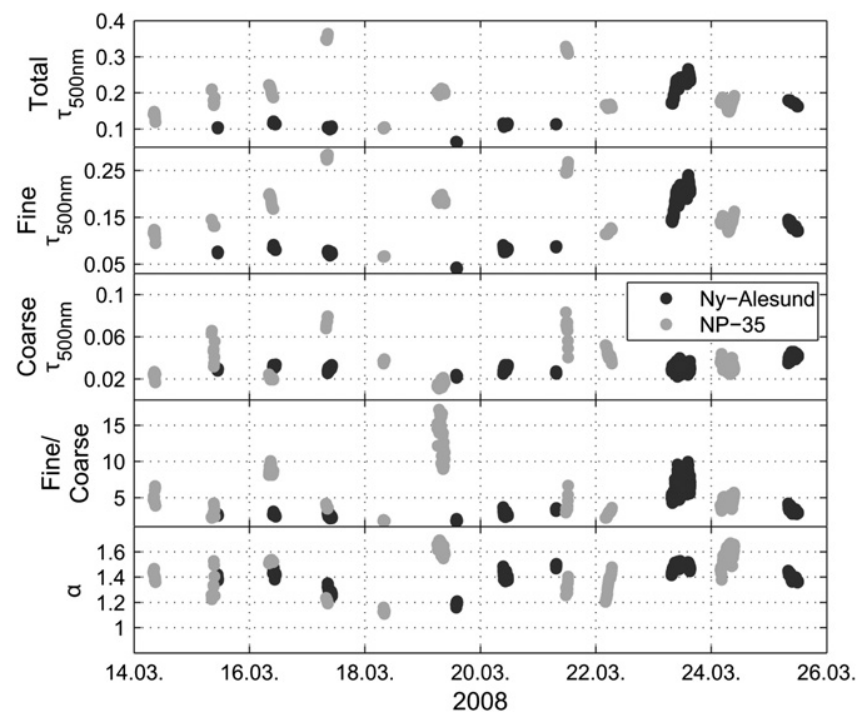

Fig. 2. Derived AOD from sun photometer measurements at the $500 \mathrm{~nm}$ wavelength and Ångström coefficient $\alpha$ in March 2008.
Table 1

Mean values and total number $N$ of sun photometer measurements in March 2008 and from three event days at NP-35 and Ny-Ålesund.

\begin{tabular}{llll}
\hline & Mean & Ny-Ålesund & NP-35 \\
\hline March 08 & $N$ & 961 & 251 \\
& $\tau_{500 \mathrm{~nm}}$ & $0.17 \pm 0.05$ & $0.19 \pm 0.05$ \\
& $\tau_{\text {fine }}$ & $0.13 \pm 0.05$ & $0.15 \pm 0.05$ \\
& $\tau_{\text {coarse }}$ & $0.03 \pm 0.05$ & $0.04 \pm 0.02$ \\
17.03 .2008 & $\alpha$ & $1.4 \pm 0.09$ & $1.4 \pm 0.19$ \\
& $N$ & & 10 \\
& $\tau_{500 \mathrm{~nm}}$ & & $0.35 \pm 0.005$ \\
& $\tau_{\text {fine }}$ & & $0.28 \pm 0.004$ \\
& $\tau_{\text {coarse }}$ & & $0.07 \pm 0.004$ \\
& $\alpha$ & & $1.2 \pm 0.01$ \\
& $N$ & & 12 \\
& $\tau_{500 \mathrm{~nm}}$ & & $0.32 \pm 0.006$ \\
& $\tau_{\text {fine }}$ & & $0.07 \pm 0.012$ \\
& $\tau_{\text {coarse }}$ & & \\
& $\alpha$ & & \\
& $N$ & 358 & \\
& $\tau_{500 \mathrm{~nm}}$ & $0.22 \pm 0.026$ & \\
& $\tau_{\text {fine }}$ & $0.19 \pm 0.026$ & \\
& $\tau_{\text {coarse }}$ & $0.03 \pm 0.004$ & \\
$\alpha$ & $\alpha$ & $1.5 \pm 0.02$ & \\
\hline
\end{tabular}

$135.07^{\circ} \mathrm{E}$ ) were reported. Maps of the aerosol index retrieved from OMI measurements (Ozone Mapping Instrument on bord of the satellite Aura) showed in the region of Khabarovsk high aerosol concentration on 09.03.2008 (see Fig. 4). This aerosol plume drifted eastward to Kamchatka and in combination with the trajectory calculation for the 17.03.2008, it can be concluded, that the high AOD at the NP-35 on 17.03.2008 was caused by the transport of biomass burning aerosols from Khabarovsk.

\section{Aerosol event on March 21 and 23}

The time series of sun photometer measurements in March 2008 in Fig. 2 shows additionally to the discussed March 17 two more days with high AOD values - March 21 at NP-35 and March 23 at NyÅlesund. The calculated trajectories for the March 21 and March 23 in Fig. 3(b) and Fig. 3(c) show for both days almost identical backward trajectories arriving from northwestern Siberia. For March 21 the output of all trajectory models is equal. Larger differences between PEP-Tracer (NCEP) and PEP-Tracer (ECMWF) can be observed on March 23. With the NCEP data the trajectories from NyÅlesund pass the position of NP-35 directly 2 days before arriving in Ny-Ålesund. The trajectories calculated with ECMWF are far southeasterly. But it still can be assumed that at NP-35 and NyÅlesund a similar aerosol event was observed and that the air mass came from the vicinity of the Northern Siberian city of Norilsk $\left(88.2^{\circ}\right.$ E, $\left.69.3^{\circ} \mathrm{N}\right)$.

Lidar observations, performed on March 23 between UT $11 \mathrm{~h}$ till $17 \mathrm{~h}$, clearly showed a persistent layer of increased backscatter around $3 \mathrm{~km}$ altitude (see Fig. 5). In this section a detailed analysis of the aerosol properties in this layer shall be given. We defined the aerosol layer by the following condition: all data points between $2.08 \mathrm{~km}$ and $3.88 \mathrm{~km}$ altitude between UT 11:10 and UT 15:40 where the aerosol backscatter $\left(\beta^{\text {aer }}\right)$ at $355 \mathrm{~nm}$ is larger than $2 \times 10^{-6} \mathrm{~m}^{-1} \mathrm{sr}^{-1}$ and $\beta_{532 \mathrm{~nm}}^{\text {aer }}>1.2 \times 10^{-6} \mathrm{~m}^{-1} \mathrm{sr}^{-1}$. At the given resolution of $60 \mathrm{~m}, 10 \mathrm{~min} 310$ data points were obtained. Also, to study possible inhomogeneities or temporal evolution of the aerosol layer, a subset from the thickest part between UT 12:30 and UT 14:30 with 194 data points was selected. A table containing the basic aerosol properties derived by lidar is given in Table 2 .

First the lidar ratio $L R$ (eqn. (3)) was inspected. For the whole layer we derived $=L R_{355 \mathrm{~nm}}=42.5 \pm 3.5 \mathrm{sr}$, $=L R_{532 \mathrm{~nm}}=$ $30.2 \pm 11.4 \mathrm{sr}$, while for the thickest part $=L R_{355 \mathrm{~nm}}=42.9 \pm 4.6 \mathrm{sr}$, 
a
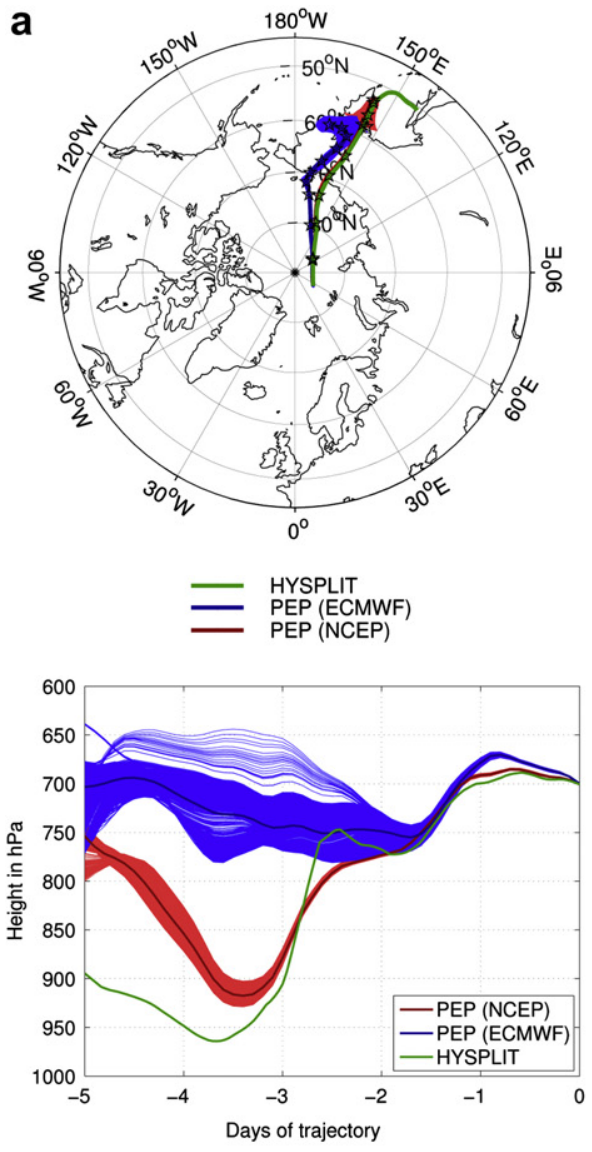

NP-35 17.03.2008 06 UT b
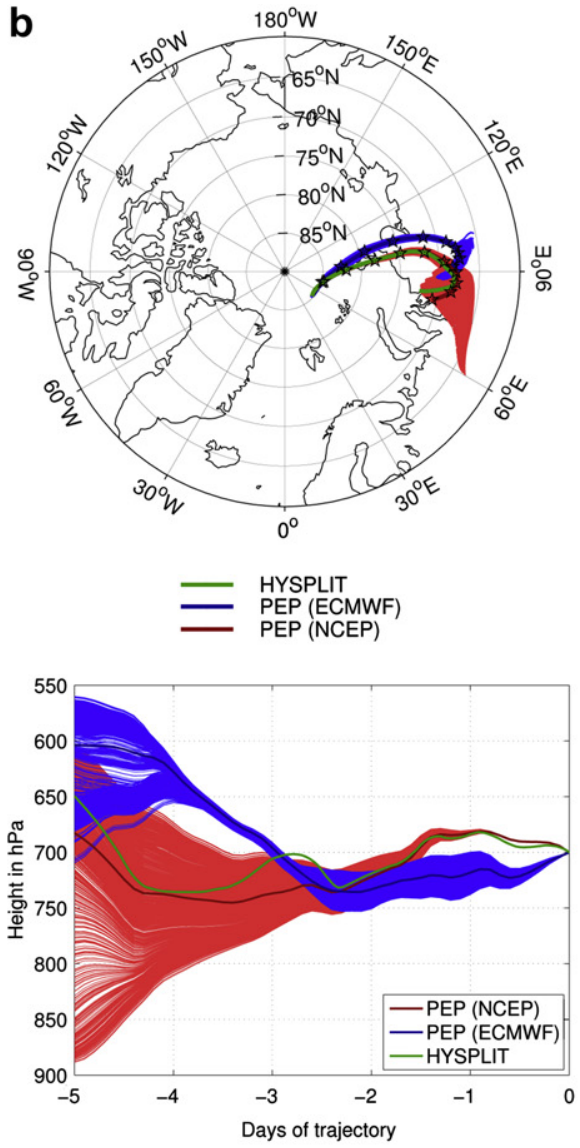

NP-35 21.03.2008 12 UT
C
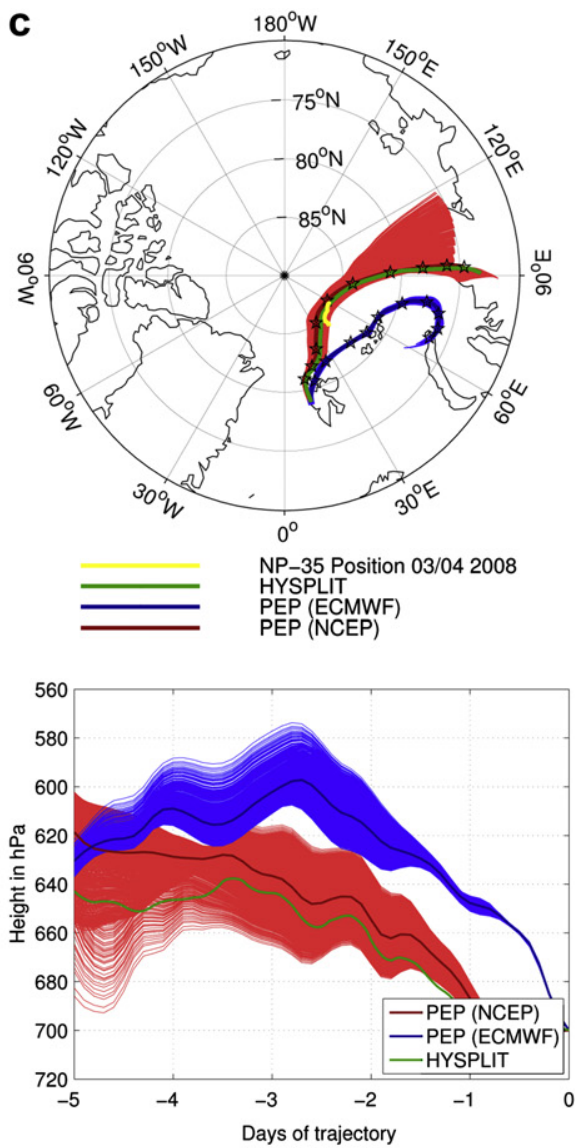

Ny-Ålesund 23.03.2008 12 UT

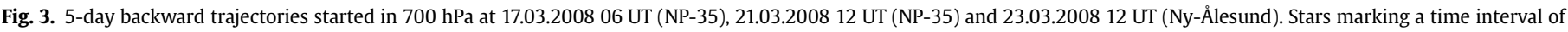

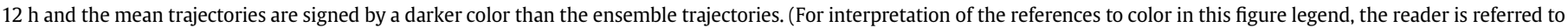
the web version of this article.)

$L R_{532 \mathrm{~nm}}=35.8 \pm 15.4 \mathrm{sr}$ was found. (The error is larger for the $532 \mathrm{~nm}$ because of two reasons. First, the Raman scattering efficiency decreases with wavelength, see U. Wandinger book chapter in Weitkamp (2005), and second, our efficiency of interference filter is lower for $532 \mathrm{~nm}$ than for $355 \mathrm{~nm}$ ) As the lidar ratio depend on size, shape and chemical composition of the aerosol, the homogeneity of the aerosol layer was checked by inspection of the correlation between $\beta^{\text {aer }}$ and $L R$. No such correlation was found (correlation coefficient $<0.3$ ). This means that border and central part of the aerosol layer have almost the same $L R$ and possible differences in the microphysics of this aerosol layer are too small to be detectable.

Next, the color ratio was inspected. As can be seen from Fig. 6(a) a quite uniform color ratio with values above 5 was found for backscatter values $\beta_{532 \mathrm{~nm}}^{\text {aer }}>10^{-6} \mathrm{~m}^{-1} \mathrm{sr}^{-1}$. This corresponds to an Ångström exponent for the backscattering of 1.6 for the whole layer and 1.55 for the central part. Similar to the Ångström exponent derived by photometer this is a rough measure of the particles' size. Again, the aerosol layer seems to be vertically homogeneous, while at low backscatter values (outside of the Haze layer) the color ratio and hence the size of the aerosol is more variable.

A similar picture is obtained by the analysis of the aerosol depolarization Fig. 6(b). The value is around $4.4 \%$. Similar to earlier findings in Ny-Ålesund for Arctic Haze (Ritter et al., 2004; Hoffmann et al., 2009) the aerosol is only slightly depolarizing and can, hence, be described with Mie theory in good approximation.
This fact allowed us to invert the lidar data (backscatter and extinction coefficients) to derive an index of refraction and a size distribution with a code from Böckmann (2001). Using Mie theory the volume distribution function with the least norm is searched which represents the lidar data. The result is presented in Fig. 7. Additionally, volume size distributions for different refractive indices derived from the sun photometer AOD measurements with the use of CIRATRA (Wendisch and von Hoyningen-Huene, 1994) are shown. The volume size distribution of the lidar at March 23 resembles very closely a (single-mode) log-normal distribution with effective radii around $185 \mathrm{~nm}$. The comparison of the different layers in Table 2 shows that the size distribution of the thickest part of the aerosol layer is very similar in shape to the one of the whole aerosol layer, only the number concentration of the particles does vary. The derived refractive index, which is higher than for purely water soluble aerosol, the widths of the distribution and the effective radius of the aerosol did not show measurable variations within the aerosol layer.

To summarize the lidar results, a thorough evaluation of lidar data has been performed to analyze this aerosol event. Moderate values of the $L R$, high values for the $C R$ and low depolarization were found. The temporal and spatial evolution of the aerosol event is close to the instrumentation detection limit. Apparently the aerosol hardly varied with respect to size, shape or chemical composition. This result is supported by inversions of the aerosol size distribution. Here a mono-modal log-normal distribution of particles in the 


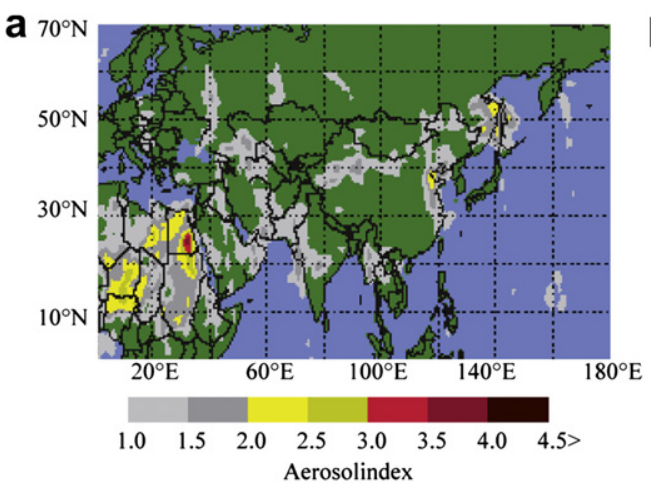

OMI 09.03.2008

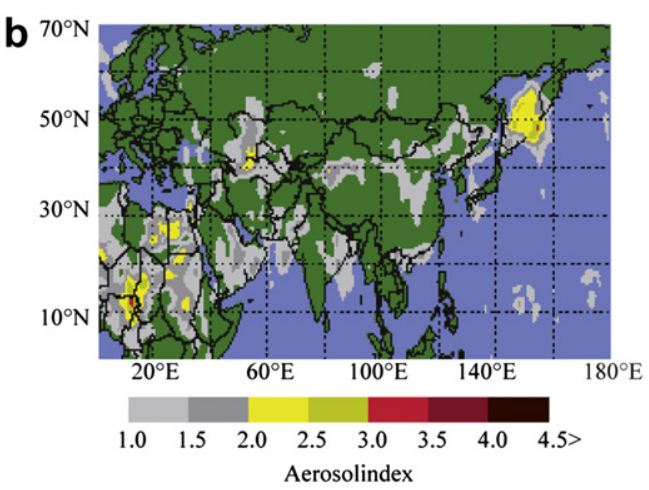

OMI 10.03.2008

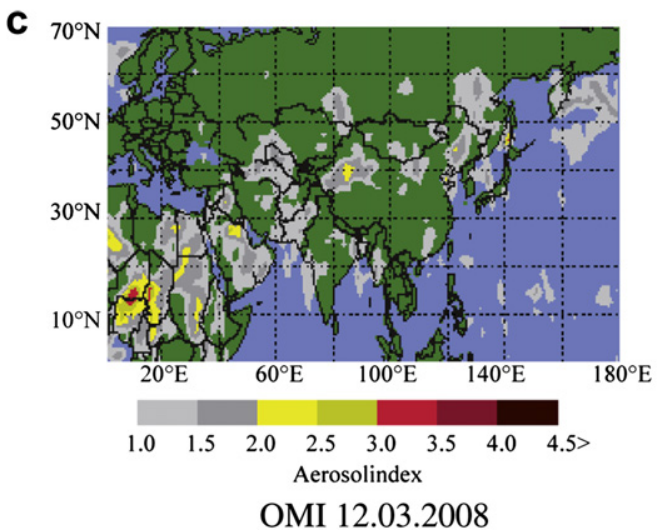

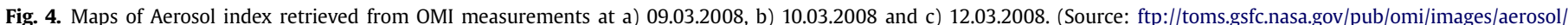
Y2008/).

accumulation mode was found with particle concentrations around $580 \mathrm{~cm}^{-3}-850 \mathrm{~cm}^{-3}$ in the thickest part.

\section{Discussion}

A summary of all photometer measurements during March 2008, both from NP-35 and Ny-Ålesund is given in Table 1. The separation in fine and coarse mode was calculated according to O'Neill et al.

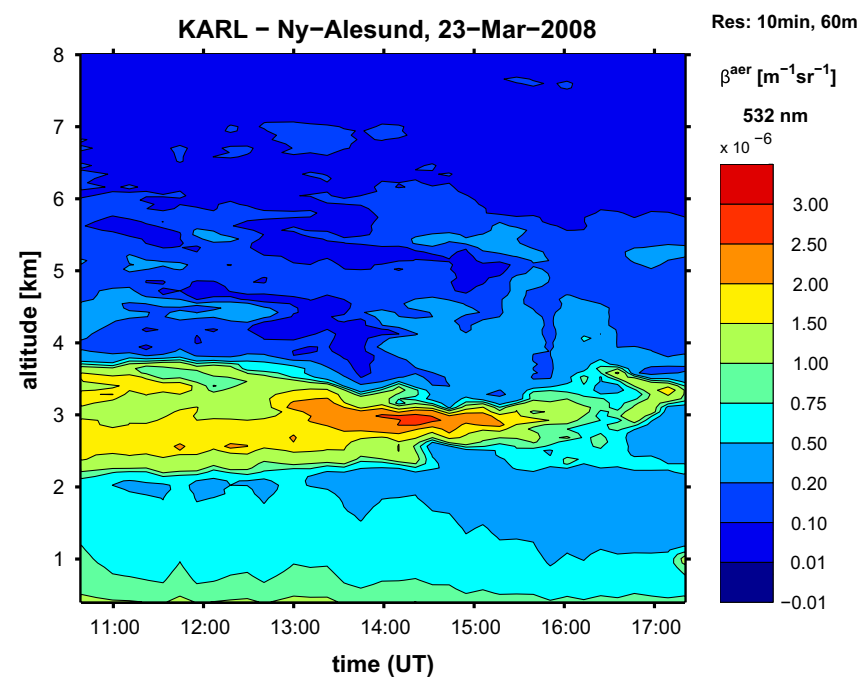

Fig. 5. Vertical profile of the backscattering coefficient measured with KARL in NyÅlesund on 23.03.2008.
(2003). Persistently the AOD over NP-35 was larger, and the 3 days with highest AOD are shown in detail. The forest fire event (March 17) showed the highest AOD recorded during the campaign. Noticeable is also the low variability for that day, both in fine and coarse mode. This stability means that neither in the aerosol layer nor below or above in the atmosphere changes occurred during this observation. At the same time the Ångström exponent $\alpha$ was slightly decreased, meaning that the particles were on average slightly larger on this day. On March 23 the highest AOD was observed over Ny-Ålesund. The AOD was already significantly lower than similar air masses 2 days before over NP-35. However, the high variability in the fine mode indicates that the aerosol event was not very uniform. From the decrease of AOD during March 21-23 one cannot easily conclude on the aerosol life time as it is possible that only a part of the aerosol event was advected to Ny-Ålesund.

The disagreement in our trajectory analysis between NCEP and ECMWF driving fields can be explained by the sparseness of

Table 2

Aerosol properties derived by lidar on March 23 in Ny-Ålesund. (whole Layer: 11:10-15:40 UT, central part: 12:30-14:30 UT).

\begin{tabular}{lcc}
\hline Parameter [unit] & Whole layer & Central part \\
\hline Lidar ratio at $355 \mathrm{~nm}[\mathrm{sr}]$ & $42.5 \pm 3.5$ & $42.6 \pm 4.6$ \\
Lidar ratio at 532 nm [sr] & $30.2 \pm 11.4$ & $35.8 \pm 15.4$ \\
Aerosol depolarization [\%] & $4.46 \pm 0.03$ & $4.32 \pm 0.036$ \\
Color ratio [-] & $5.29 \pm 0.06$ & $5.47 \pm 0.08$ \\
Re refractive index [-] & $1.6 \pm 0.1$ & $1.6 \pm 0.1$ \\
$I M$ refractive index [-] & $0.007 \pm 0.007$ & $0.007 \pm 0.007$ \\
Effective radius [ $\mu \mathrm{m}]$ & $0.185 \pm 0.01$ & $0.185 \pm 0.01$ \\
Aerosol number concentration $\left[\mathrm{cm}^{-3}\right]$ & $580 \pm 100$ & $850 \pm 100$ \\
Sigma [-] & $1.636 \pm 0.06$ & $1.64 \pm 0.06$ \\
\hline
\end{tabular}



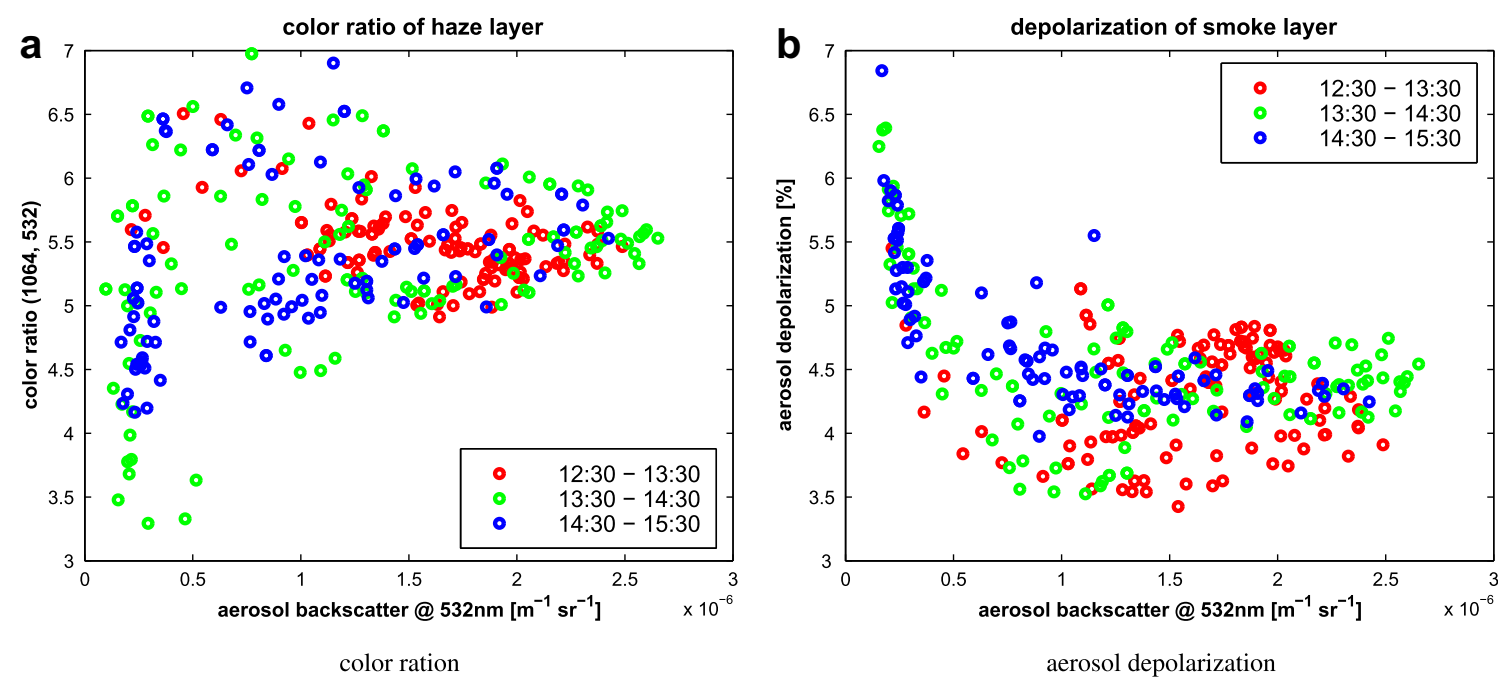

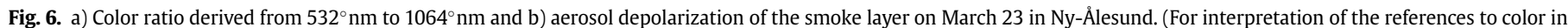
this figure legend, the reader is referred to the web version of this article.)

meteorological data in the central Arctic. Damoah et al. (2004) found good agreement between these both data sets for 17 days for trajectories along the Arctic circumference. For the data presented here a connection between the Khabarovsk or biomass burning event and the observations on NP-35 on March 17 seems to be clear. Moreover, the probability that (almost) the same air mass was observed over NP-35 on March 21 and Ny-Ålesund on March 23 is very high. We carefully checked with both data sets and different forward and backward calculations the possibility that the March 21 and 23 cases might also have been influenced by the Khabarovsk fires. However, no such connection has been found. Instead these latter cases are probably influenced by source close to Norilsk. For that reason we have to distinguish between the forest fire case and the typical Arctic Haze.

Nevertheless, there is a similarity for all three days of high AOD in the radio soundings: All show a minimum of the relative humidity at $2.4 \mathrm{~km}$ altitude (see Fig. 8 ). In the same height the aerosol layer has been detected by the lidar in Ny-Ålesund. If such a decrease in humidity were caused by the aerosol it requires sufficient hygroscopic supermicron particles to be present in the

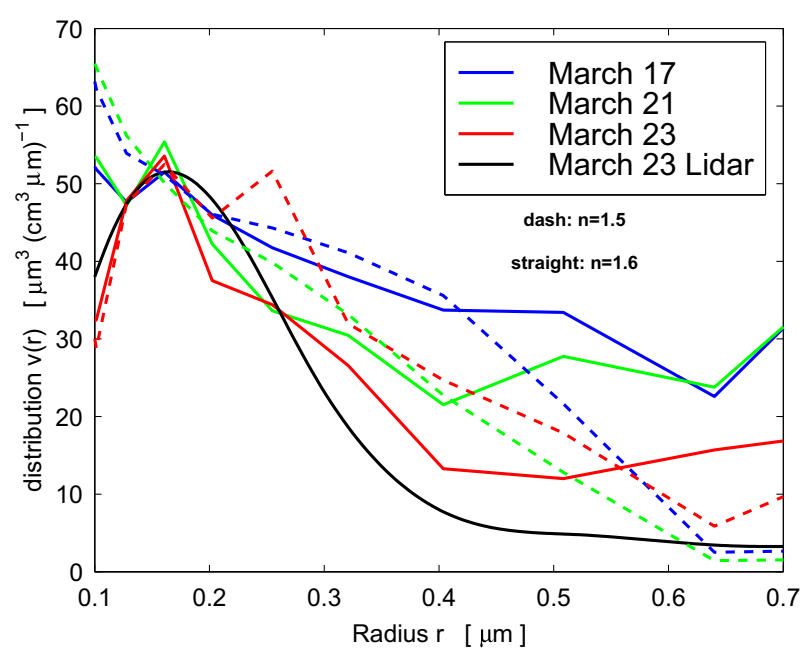

Fig. 7. Volume size distributions derived from sun photometer and lidar measurements in March 2008. fresh aerosol layer, which then further grew due to water uptake, sedimented out and hence were not observed. The accumulation mode particles found here have a too small volume to take up a significant amount of water vapor any longer. For this reason the water gap slowly vanishes due to Brownian motion and is not so pronounced on March 23 than it was earlier. Moreover the high index of refraction also suggests that predominantly dark and insoluble aerosol was observed.

Generally it is difficult to judge the mean particle diameter of an aerosol layer from photometer measurements alone, as the Ångström exponent is a mean of the whole troposphere and possible snow drift above the ground or subvisible cirrus clouds in the free troposphere, both phenomena are not uncommon in the Arctic, might spuriously indicate an increase of particle diameter. Therefore we applied the spectral deconvolution of the photometer data which shows that all 3 days of high AOD under consideration are marked by an increase of the fine mode only (see Fig. 2 and Table 1).

The derived lidar ratios for this case are similar to values which were derived for Arctic Haze cases in 2007 (Hoffmann et al., 2009) and 2009 (Hoffmann, 2011). For the lower free troposphere typically values around $30 \mathrm{sr}-60 \mathrm{sr}$ for $532 \mathrm{~nm}$ and 25-50 sr for $355 \mathrm{~nm}$ were found over Spitsbergen. However, the March 23 case is the first one observed with KARL so far where the lidar ratio at $355 \mathrm{~nm}$ surpasses the one at $532 \mathrm{~nm}$. While Müller et al. (2007) emphasized the usage of the spectral shape of the lidar ratio to classify aerosol (and found lidar ratios around $60 \mathrm{sr}$ for both colors and Arctic Haze themselves), interestingly the values found here did not noticeably influence the inverted refractive index (which is typical around 1.5-1.55 over Ny-Ålesund for Haze (Hoffmann, 2011)) nor the volume distribution.

The comparison of volume size distributions derived from photometer and lidar measurements in Fig. 7 shows a high agreement in the accumulation particle mode. The photometer inversions were performed with two refractive indices, 1.6, as was derived by lidar, and 1.5 . The differences in both solutions are minimal for particles with sizes around the effective radii. For larger particles deviations in the volume distribution function are evident but the lidar inversion for March 23 indicates that particles larger than $0.3 \mu \mathrm{m}$ might be predominantly located outside the aerosol layer. As stated above the high refractive index suggests that a high fraction of incomplete combustion remnants 


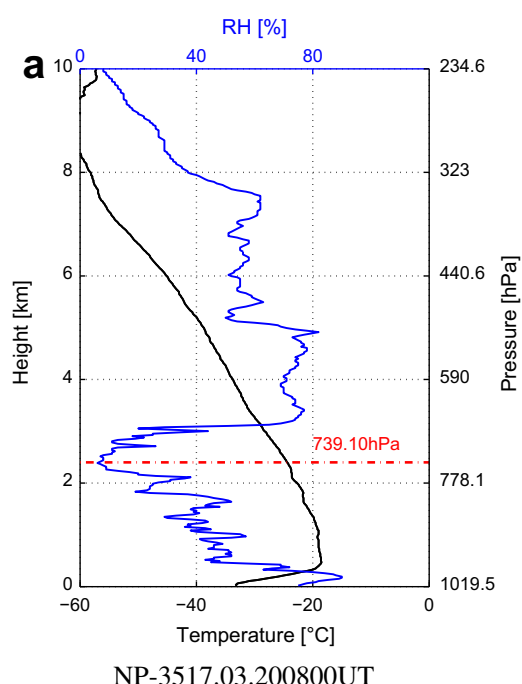

NP-3517.03.200800UT

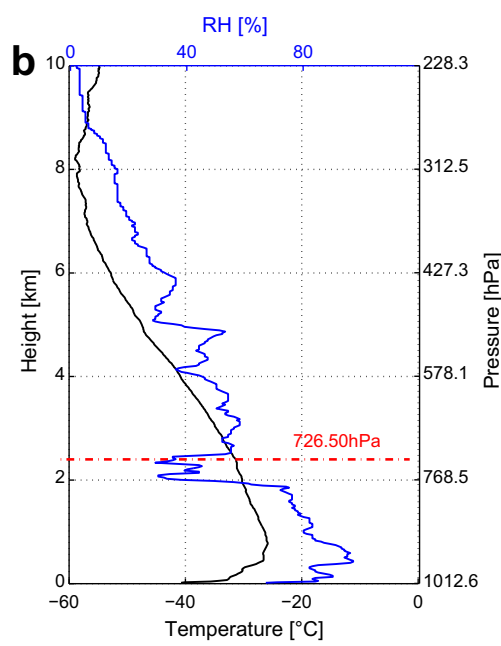

NP-3521.03.200800UT

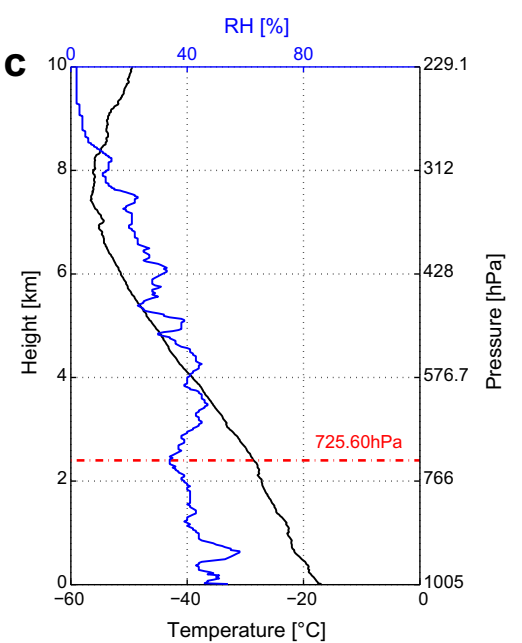

Ny-Ålesund23.03.200811UT

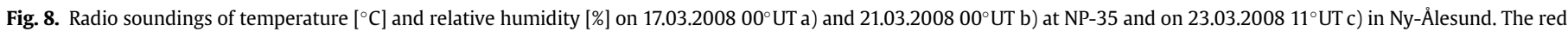
dotted line marks the height of $2.4^{\circ} \mathrm{km}$. (For interpretation of the references to color in this figure legend, the reader is referred to the web version of this article.)

as black carbon have been present in the aerosol. As the lidar data were derived only from the apparent aerosol layer $(2.08-3.88 \mathrm{~km}$ altitude) and not from the whole troposphere the high agreement between photometer and lidar derived volume distribution function for March 23 and particles around $0.2 \mu \mathrm{m}$ radius also indicates the dominance of the observed aerosol layer. Apparently, aerosol of this size is almost exclusively present in this altitude. In total the photometer correctly shows more aerosol volume but the larger particles are probably located outside the aerosol layer. The volume size distributions for March 21 and 23 (classical Arctic Haze) are more similar among each other with less particles larger than $0.3 \mu \mathrm{m}$ radius than for the Khabarowsk event on March 17 (which is consistent to the higher Ångström exponent). As aerosol with $0.2 \mu \mathrm{m}$ radius has the longest life time in the atmosphere (Twomey, 1977) the narrower distributions around this value for March 21 and 23 suggests that either these aerosols are even older than the Khabarovsk event, that took 11 days to move from eastern Siberia above the NP-35. Or, more probable, if the classical Arctic Haze came from Norilsk (and hence was only three to five days old then observed) it means that classical anthropogenic Arctic Haze might contain smaller particles in average compared to biomass burning. In any case we can confirm life time of Arctic aerosol of two weeks under favorable conditions (low precipitation in the dominating high pressure system shown in Fig. 1) which in turn means that it will be almost impossible to understand the origin of the Arctic aerosol from few stations and classical trajectory analysis alone. A long life time of up to 30 days in Arctic wintertime atmosphere for particles of the inverted size was already found by Korhonen et al. (2008). Based on our limited data set it would be interesting to see to what extent the occurrence of aerosol with radii between 0.4 and $0.7 \mu \mathrm{m}$ might serve as an indicator of age, independent of origin. Such a suggestion can be drawn by the differences in volume distribution between March 21 and 23 assuming that almost the same air mass has been seen. Based on the derived distribution functions about 15 aerosol particles per $\mathrm{ccm}$ in the range of $0.4-0.7 \mu \mathrm{m}$ have been found for March 17, 11 for March 21 and only 6 for March 23. As particles of this size sediment down with approximately $300 \mathrm{~m}$ per day this decrease might be an aging effect. On the other hand meteorological changes outside the aerosol layers cannot be neglected. For a more precise analysis of aerosol aging effects a lidar at NP-35 would be needed.

\section{Conclusion}

The presented analysis clearly shows the importance of aerosol measurements in the Central and Russian Arctic to interpret observations in the European Arctic. Without photometer measurements at NP-35 the strong Khabarovsk forest fire event would have been completely unnoticed, despite its significant impact on AOD in the central Arctic.

During March 2008 the measured AOD was systematically higher over NP-35 than over Ny-Ålesund, even without the forest fire event. This result is astonishing if anthropogenic sources in Europe were the main cause of Arctic Haze. Therefore, sources in Asia, both natural or man-made are possibly more dominant.

However, air back trajectories still have their limitations in the Arctic. Our comparison between 2 models and 2 meteorological fields clearly showed that for our data the meteorological field (and the rareness of observational data) limits the precision of the trajectory calculation above 5 days at most. Even ensemble trajectories are not immune against this. In Fig. 3(c) the PEP-tracer model with ECMWF and NCEP diverge without overlap into (slightly) different source regions already after few hours. Only due to combined observations at NP-35 and in Ny-Ålesund we have hints that for this special case NCEP seems to be better suited, but this singular result should not be generalized. However it seems recommendable to use ensemble trajectories with different meteorological fields for remote sites to see the limits in the analysis.

With the exception of the three events discussed we could not link the increased AOD to singular sources. As the forest fire aerosol needed almost 2 weeks before they were advected to NP-35 this confirms the long life time of aerosol in the Arctic wintertime troposphere.

A slightly novel approach for the retrieval of extinction from lidar data, using high resolution, unsmoothed lidar profiles and correlations between the (noisy) lidar ratio with the backscatter or depolarization has been used. However, no correlations have been found, meaning that the aerosol layer observed was quite homogeneous in terms of the aerosol microphysics. Only the number concentration seems to vary between the central part and the edges of the layer. This means that a gravitational sinking (large particles on the bottom and small particles up) has not been seen.

The inversion of the microphysics from photometer data for all three days and for lidar on March 23 gave roughly similar volume 
distribution functions with effective radii around $0.2 \mu \mathrm{m}$. The distribution is wider for the Khabarovsk event, probably due to its possible different origin. In any case differences in optical remote sensing data between the Khabarovsk forest fire and the Siberian cases in observed quantities (Ångström exponent) as well as in derived parameters (distribution functions) are only subtle. Hence, from remote sensing alone it could be challenging to assign a clear origin to an observed aerosol case. Conversely this means that the radiative forcing of Arctic Haze does not strongly depend on its cause, may it be natural forest fire or anthropogenic. However, a more complete data set is needed to confirm this finding. Even a month long observation campaign showed only a limited number of strong Arctic Haze and Smoke cases (additionally to an increased, persistent AOD over the central Arctic ocean). Surely more coordinated campaigns with the inclusion of airborne and satellite systems are required to better understand the pollution pathways and transformation processes of aerosol in this sensitive environment.

\section{Acknowledgments}

We would like to acknowledge N. O'Neill for providing the spectral deconvolution code. Special thanks we would like to give to our Russian partner V. Sokolov from the Arctic and Antarctic Research Institute (AARI) in St. Petersburg. His cooperation and organization efforts where essential for the successful participation of J. Gräser (AWI) at NP-35.

\section{References}

Ångström, A., 1929. On the atmospheric transmission of sun radiation and on dust in the air. Geografiska Annaler 11, 156-166.

Ansmann, A., Wandinger, U., und, C., Weitkamp, U.R., Michaelis, W., 1992. Independent measurement of extinction and backscatter profiles in cirrus clouds by using a combined Raman elastic-backscatter lidar. Appl. Opt. 31, 7113-7131.

Barrie, L., 1986. Arctic air pollution: an overview of current knowledge. Atm. Env 20, 643-663.

Behrendt, A., Nakamura, T., 2002. Calculation of the calibration constant of polarization lidar and its dependency on atmospheric temperature. Opt. Express 10, 805-817.

Böckmann, C., 2001. Hybrid regularization method for the ill-posed inversion of multiwavelength lidar data to determine aerosol size distribution. Appl. Opt. 40, 1329-1342.

Clarke, A., Noone, K., 2007. Soot in the arctic snowpack: a cause for perturbations in radiative transfer. Atm. Env. 41, 64-72.

Damoah, R., Spichtinger, N., Forster, C., James, P., Mattis, I., Wandinger, U., Beirle, S., Wagner, T., Stohl, A., 2004. Around the world in 17 days hemispheric-scale transport of forest fire smoke from Russia in May 2003. Atmos. Chem. Phys. 4,1311-1321.

Draxler, R., Rolph, G., 2003. HYSPLIT (HYbrid Single-particle Lagrangian Integrated Trajectory) Model Access via NOAA ARL READY Website. Technical Report. NOAA Air Resources Laboratory, Silver Spring, MD.

Flanner, M., Zender, C., Randerson, J., Rasch, P., 2007. Present-day climate forcing and response from black carbon in snow. J. Geophys. Res. 112, D11202.

Fu, P., Kawamura, K., Barrie, L., 2009. Photochemical and other sources of organic compounds in the Canadian high Arctic aerosol pollution during winter-spring. Environ. Sci. Technol. 43, 286-292.

Herber, A., Thomason, L., Gernandt, H., Leiterer, U., Nagel, D., Schulz, K.H., Kaptur, J., Albrecht, T., Notholt, J., 2002. Continuous day and night aerosol optical depth observations in the arctic between 1991 and 1999. J. Geophys. Res. 107.

Hoffmann, A., Ritter, C., Stock, M., Shiobara, M., Lampert, A., Maturilli, M., Orgis, T. Neuber, R., Herber, A., 2009. Ground-based lidar measurements from Ny-Ålesund during Astar 2007. Atmos. Chem. Phys. 9, 15453-15510.

Hoffmann, A., 2011. Comparative Aerosol Studies based on Multi-wavelength Raman LIDAR at Ny-Ålesund, Spitsbergen. Ph.D. thesis. University Potsdam.

Kasischke, E., Hyer, E., French, N., Suchinin, A., Hewson, J., Stocks, B., 2004. Carbon emissions from boreal forest fires 1996 to 2002. Glob. Biogeochem. Cycles 19, GB1012.

Klett, J., 1985. Lidar inversion with variable backscatter/extinction ratios. Appl. Opt. 24, 1638-1643.

Koch, D., Hansen, J., 2005. Distant origins of arctic black carbon: a Goddard Institute for Space Studies Modele experiment. J. Geophys. Res. 110, D04204.

Korhonen, H., Carslaw, K.S., Spracklen, D.V., Ridley, D.A., Ström, J., 2008. A global model study of processes controlling aerosol size distributions in the Arctic spring and summer. J. Geophys. Res. 113, D08211.
Law, K., Stohl, A., 2007. Arctic air pollution: origins and impacts. Science 315, 1537-1540.

Liu, Z., Sugimoto, N., Murayama, T., 2002. Extinction-to-backscatter ratio of Asian dust observed with high-spectral-resolution lidar and Raman lidar. Appl. Opt. 41, 2760-2767.

Malevsky-Malevich, S., Molkentin, E., Nadyozhina, E., Shklyarevich, O., 2008. An assessment of potential change in wildfire activity in the Russian boreal forest zone induced by climate warming during the twenty-first century. Climatic Change 86, 463-474.

Müller, D., Ansmann, A., Mattis, I., Tesche, M., Wandinger, U., Althausen, D. Pisani, G., 2007. Aerosol-type-dependent lidar ratios observed with Raman lidar. J. Geophys. Res. 112, D16202.

O’Neill, N., Eck, T., Holben, B., Smirnov, A., Dubovik, O., 2001. Bimodal size distribution influences on the variation of angstrom derivatives in spectral and optical depth space. J. Geophys. Res. 106, 9787-9806.

O'Neill, N., Eck, T., Smirnov, A., Holmen, B., Thulasiraman, S., 2003. Spectral discrimination of coarse and fine mode optical depth. J. Geophys. Res. 108, 4559

Orgis, T., Brand, S., Schwarz, U., Handorf, D., Dethloff, K., Kurths, J., 2009. Influence of interactive stratospheric chemistry on large-scale air mass exchange in a global circulation model. Eur. Phys. J. Spec. Top. 174, 257-269.

Pornsawad, P., Böckmann, C., Ritter, C., Rafler, M., 2008. The ill-posed retrieval of aerosol extinction coefficient profiles from Raman lidar by regularization. Appl. Opt. 47, 1649-1661.

Quinn, P., Shaw, G., Andrews, E., Dutton, E., Ruoho-Airola, T., Gong, S., 2007. Arctic haze: current trends and knowledge gaps. Tellus 59B, 99-114.

Rahn, K., 1981. Relative importances of North America and Eurasia as sources of Arctic aerosol. Atm. Env. 15, 1447-1455.

Ramanathan, V., Carmichael, G., 2008. Global and regional climate changes due to black carbon. Nat. Geosci. 1, 221-227.

Rinke, A., Dethloff, K., Fortmann, M., 2004. Regional climate effects of arctic haze Geophys. Res. Lett. 31.

Ritter, C., Kirsche, A., Neuber, R., 2004. Tropospheric aerosol characterized by a Raman lidar over Spitsbergen. In: ESA SP 561, vol. 22. ILRC, pp. 459-462.

Soja, A.J., Tchebakova, N.M., French, N.H.F., Flannigan, M.D., Shugart, H.H., Stocks, B.J., Sukhinin, A.I., Parfenova, E.I., Chapin, F.S., Stackhouse, P.W., 2007. Climate-induced boreal forest change: Predictions versus current observations. Glob. Planetary Change 56, 274-296.

Stock, M., 2010. Charakterisierung der troposphärischen Aerosolvariabilität in der europäischen Arktis. Ph.D. thesis. University Potsdam.

Stohl, A., Andrews, E., Burkhart, J., Forster, C., Herber, A., Hoch, S., Kowal, D. Lunder, C., Mefford, T., Ogren, J., Sharma, S., Spichtinger, N., Stebel, K., Stone, R. Strm, J., Tørseth, K., Wehrli, C., Yttri, K., 2006. Pan-arctic enhancements of light absorbing aerosol concentrations due to North American boreal forest fires during summer 2004. J. Geophys. Res. 111.

Stohl, A., Berg, T., Burkhart, J., Fjæraa, A., Forster, C., Herber, A., Hov, Ø, Lunder, C. McMillan, W., Oltmans, S., Shiobara, M., Simpson, D., Solberg, S., Stebel, K. Strm, J., Tørseth, K., Treffeisen, R., Virkkunen, K., Yttri, K., 2007. Arctic Smoke record high air pollution levels in the European arctic due to agricultural fires in Eastern Europe in spring 2006. Atmos. Chem. Phys. 7, 511-534.

Stohl, A., 1998. Computation, accuracy and application of trajectories - a review and bibliography. Atm. Env. 32, 947-966.

Stone, R., Anderson, G., Shettle, E., Andrews, E., Loukachine, K., Dutton, E., Schaaf III, C., Roman, M., 2008. Radiative impact of boreal smoke in the arctic: observed and modeled. J. Geophys. Res. 113, D14S16.

Stroeve, J., Holland, M., Meier, W., Scambos, T., Serreze, M., 2007. Arctic sea ice decline: faster than forecast. Geophys. Res. Lett. 34, L09501.

Treffeisen, R., Rinke, A., Fortmann, M., Dethloff, K., Herber, A., Yamanouchi, T., 2005. A case study of radiative effects of Arctic aerosols in March 2000. Atm. Env. 39, 899-911.

Twomey, S., 1977. Atmospheric Aerosols. Developments in Atmospheric Science, vol. 7. Elsevier Scientific Publishing Company.

Warneke, C., Bahreini, R., Brioude, J., Brock, C., de Gouw, J., Fahey, D., Froyd, K. Holloway, J., Middlebrook, A., Miller, L., Montzka, S., Murphy, D., Peischl, J. Ryerson, T., Schwarz, J., Spackman, J., Veres, P., 2009. Biomass burning in Siberia and Kazakhstan as an important source for haze over Alaskan arctic in April 2008. Geophys. Res. Lett. 36.

Warneke, C., Froyd, K., Brioude, J., Bahreini, R., Brock, C., Cozic, J., de Gouw, J., Fahey, D., Ferrare, R., Holloway, J., Middlebrook, A., Miller, L., Montzka, S. Schwarz, J., Sodemann, H., Spackman, J., Stohl, A., 2010. An important contribution to springtime Arctic aerosol from biomass burning in Russia. Geophys. Res. Lett. 37, L01801.

Weitkamp, C., 2005. Lidar Range-resolved Optical Remote Sensing of the Atmosphere. Springer

Wendisch, M., von Hoyningen-Huene, W., 1994. Possibility of refractive index determination of atmospheric aerosol particles by ground-based solar extinction and scattering measurements. Atm. Env 28, 785-792.

WMO, 1996. Guide to Meteorological Instruments and Methods of Observation. World Meteorological Organisation. Geneva WMO-No.8.

Yamanouchi, T., Treffeisen, R., Herber, A., Shiobara, M., Yamagata, S., Hara, K. Sato, K., Yabuki, M., Tomikawa, Y., Rinke, A., Neuber, R., Schumachter, R. Kriews, M., Ström, J., Schrems, O., Gernandt, H., 2005. Arctic study of tropospheric aerosol and radiation (astar) 2000: Arctic Haze case study. Tellus 57B, $141-152$. 